\title{
Nomination of Insurance Policy for Singaporean Muslims
}

\author{
(Penamaan di dalam Polisi Insuran bagi Masyarakat Islam Singapura) \\ Suhaili Alma'amun \\ (Faculty of Economics and Management, Universiti Kebangsaan Malaysia) \\ Mohd Khairy Kamarudin \\ (Faculty of Entrepreneurship and Business, Universiti Malaysia Kelantan)
}

ABSTRACT

The permissibility of a revocable nomination of insurance policies is the recent fatwa issued by the Fatwa Committee of Islamic Religious Council of Singapore (MUIS). This validation is derived by making an analogy between hibah and its revocable nomination. The fatwa has been changed with the aim to harmonise the Syariah law with Insurance Act S49L and simplify the estate administration and distribution process for Singaporean Muslims. In Malaysia, hibah of takaful benefits has been employed by the takaful providers and the operational framework varies across these takaful providers. Hibah of takaful benefits has been in operation for sometime in the absence offatwa that validates the operational framework of this product at the national level. This study aims to explore the revocable nomination of insurance policies for Muslims in Singapore by means of semi-structured interviews and content analysis on secondary data namely statutes and fatwas. This study finds that the purpose of this fatwa amendment is to reinforce the method used to meet the objective of Islamic estate planning of Muslims'domicile in Singapore taking into account that civil law supersedes the Islamic law. Fatwa issued in Singapore also applies to takaful funds but the fatwa treats both accounts in takaful funds similarly. Unlike Malaysia, the heritability of tabarru'funds in takaful is still debatable. The fatwa is non-binding and thus, it raises the concern of a conflict existing between the existing laws and this fatwa which finally challenges the extent to which the fatwa is applicable. The current fatwa has received various feedbacks from the Islamic estate planners in Singapore and the suggestion of considering an additional legal document for the so-called 'contemporary hibah' is also highlighted. This study suggests that both countries benefit can from each other's practice.

Keywords: Hibah; revocable nomination; insurance; takaful; Islamic estate planning

ABSTRAK

Kebenaran untuk membuat penamaan yang boleh ditarikbalik di dalam polisi insurans adalah fatwa terkini yang dikeluarkan oleh Jawatankuasa Fatwa Majlis Ugama Islam Singapura (MUIS). Pengesahan ini telah dibuat secara analogi antara hibah dan penamaan yang boleh ditarikbalik. Fatwa ini telah diubah dengan tujuan untuk mengharmonikan undang-undang Syariah dan Akta Insuran S49L serta memudahkan proses pentadbiran dan pengagihan harta pusaka bagi masyarakat Islam di Singapura. Di Malaysia, hibah manfaat takaful telah dilaksanakan oleh pengendali takaful dan rangka kerja operasinya adalah berbeza di antara pengendali produk takaful. Hibah manfaat takaful telah dijalankan walaupun tiada fatwa yang mengesahkan rangkakerja produk ini di peringkat kebangsaan. Kajian ini bertujuan untuk mengkaji penamaan yang boleh ditarikbalik di dalam polisi insurans untuk masyarakat Islam di Singapura melalui temubual separa berstruktur dan analisis kandungan ke atas data sekunder iaitu statut dan fatwa. Kajian ini mendapati bahawa pemindaan ke atas fatwa adalah untuk memperkukuhkan lagi kaedah yang boleh digunakan bagi memenuhi objektif perancangan harta pusaka orang Islam yang menetap di Singapura dengan mengambilkira peruntukkan di mana undangundang sivil mengatasi undang-undang Islam. Fatwa yang dikeluarkan di Singapura juga terguna pakai ke atas polisi takaful tetapi fatwa tersebut melihat kedua-dua akaun di dalam polisi takaful sebagai sama. Tidak seperti di Malaysia, pewarisan tabung untuk tujuan tabarru' (sedekah) masih diperbahaskan. Fatwa yang dikeluarkan tidak mengikat dan ini menimbulkan kerisauan ke atas kemungkinan konflik yang akan berlaku di antara undang-undang yang sudah wujud serta fatwa tersebut, yang akhirnya akan mencabar sejauh manakah fatwa tersebut boleh diaplikasikan. Fatwa terkini ini telah menerima pelbagai maklumbalas daripada perancang harta pusaka Islam di Singapura dan cadangan seperti mempertimbangkan untuk membuat dokumen perundangan tambahan yang sah untuk perkara yang dianggap sebagai 'hibah kontemporari' ini turut sama diutarakan. Oleh yang demikian, kajian ini mencadangkan kedua-dua negara perlu mengambil manfaat daripada perlaksanaan yang berbeza di antara kedua-dua buah negara ini.

Kata kunci: Hibah; penamaan yang boleh ditarikbalik; insuran; takaful; perancangan harta pusaka Islam 


\section{INTRODUCTION}

Malaysia is the pioneer of Islamic insurance with the establishment of Takaful Malaysia Sdn. Bhd. in 1985 (Ab. Ghani 1999). To date, Malaysia has 12 takaful operators consisting of nine local and three international takaful operators (Bank Negara Malaysia (BNM) 2012). The escalating number of the takaful operators is meant to serve the increasing demand of Islamic insurance as the alternative to conventional insurance. Takaful is a tool to protect risk in the contextual form of Islamic financial planning and wealth management. However, if the takaful benefit is unable to be distributed to the eligible heirs, it will therefore contribute to the escalating number of frozen estates in Malaysia which is now valued at RM42 billion (Baharin 2011). Within this contextual framework, the manner of which takaful benefit is distributed has transformed tremendously from a simple nomination to a more complex mechanism known as 'hibah of takaful benefits.' Hibah of takaful benefits is a mean of estate disposal in which a takaful participant gives away his/ her takaful benefit as hibah to one or more beneficiaries. Such transformation is believed to enhance the viability of the takaful product for the purpose of the estate distribution. This is also perceived as one of the current developments or innovations of takaful products from the Malaysian Islamic estate planning point of view. This approach has been adopted by Etiqa Takaful Bhd., Syarikat Takaful Malaysia Bhd., MAA Takaful Bhd., Takaful Ikhlas Sdn. Bhd. and HSBC Amanah Takaful (Malaysia) Bhd. (Abdullah \& Abdul Aziz 2010; Nor Muhamad 2010).

The same view is shared among Muslim Singaporeans, but in a slightly different scenario. Unlike Malaysia, the takaful industry in Singapore is still small and has not yet penetrated retail markets. Hence, the necessity of the conventional insurance for Singaporean Muslims is recognised by the Fatwa Committee of Islamic Religious Council of Singapore (MUIS). Nevertheless, the need for a quick and smaller procedure of estate administration and distribution with reference to the insurance policy is recognised by the Fatwa Committee of MUIS. In the quest of searching the most efficient method of estate disposal in regard to the insurance policy, the Fatwa Committee of MUIS has changed their fatwa several times after taking into account several factors, namely legislation and implications that have arisen from the previous fatwa. Recently, the Fatwa Committee of MUIS has just issued a fatwa validating the revocable nomination of insurance policies. This validation is derived by making an analogy between hibah and a revocable nomination.

The implementation of hibah of takaful benefit in Malaysia is one of the key areas of Islamic estate planning that attracts many researchers to delve into this issue. Extensive discussion on the product has been delivered in previous studies ranging from operational framework, legislation and Islamic jurisprudence. ${ }^{1}$ On the other hand, research on Islamic estate planning among Singaporean Muslims is scarce. A number of studies is available but these studies are concerned about another mechanism of estate planning namely nuzriah, ${ }^{2}$ joint-tenancy in Housing Development Board (HDB) property ownership and Central Provident Fund (CPF) nomination. Rasban (2012) provides a preliminary study on irrevocable and revocable nomination used in insurance. Nevertheless, a depth discussion on the permissibility of revocable nomination used to distribute the insurance monies payable to the beneficiaries of Singaporean Muslim policy holders from the Islamic estate planning point of view is absent. Thus, it triggers this study to delve into this new area of Islamic estate planning in Singapore by making reference to practice in Malaysia.

We believe this study would provide new insights which are beneficial for both countries. This paper contains nine sections. It begins with an introduction that presents brief discussion of the paper. The process of the estate administration for Muslims in Singapore is covered in section two. The third section discusses hibah from the Shariah jurisprudence point of view while the fourth section elaborate implications of fatwas on join-tenancy and CPF monies in Singapore within the context of Islamic estate planning. The next section presents the takaful nomination and hibah of takaful benefits in Malaysia. The research methodology can be observed in section six and finding and discussion in section seven. Implications and recommendations are in the penultimate section and section nine concludes the paper.

\section{ESTATE ADMINISTRATION FOR MUSLIMS IN SINGAPORE}

Singapore law provides that Muslim estates are governed by Muslim laws of inheritance as stipulated in the Administration of Muslim Law Act (AMLA). In the case of a Muslim dying intestate, the estates shall be distributed in accordance with Muslim law. Accordingly, estate disposal by means of a will which violates the one-third rule or be given to the eligible heirs who are entitled to receive their quantum of shares according to the prescribed faraid rules as well as by nomination of insurance policies are not permitted. ${ }^{3}$ However, this national statute has to be read together with other acts, namely the Central Provident Fund (CPF) Act, the Conveyancing and Law of Property Act (CLPA) and the Insurance Act. Under AMLA, Islamic law prevails over civil law in matters of marriage, divorce, guardianship and inheritance that pertain to Muslims in Singapore. In spite of this, if there is a conflict of laws in matters other than those covered by AMLA such as joint tenancy, insurance and Central Provident Fund (CPF) nomination, the civil law supersedes the law prescribed within AMLA (Rasban 2010a; Rasban 2010b). Hence, this implies that Singaporean Muslims have to deal with both the Syariah and civil courts in arranging for the disposition of a Muslim's estates.

The administrative process of the deceased's estates, depending on the value of the estates, starts with obtaining a Certificate of Inheritance from the Syariah Court. The Public Trustee administers small estates of deceased 
persons where the value of the estate does not exceed $\$ 50,000$ (excluding Central Provident Fund (CPF) monies) and Letters of Administration are needed if the Public Trustee agrees to administer an estate. On the other hand, if the Public Trustee is unable to administer the estate, the heirs may have to apply to the Courts for Letters of Administration to handle with the deceased's estate.

If the deceased died intestate or if no executor is appointed by will or no executor is able to act, the court may grant Letters of Administration to the spouse of the deceased or the deceased's next of kin, or, where no such person applies, the creditor of the deceased. Security in the form of a bond in the amount equal to the gross value of the deceased's estate is to be provided by the person applying for a grant of letters of administration, and by two sureties, unless the court orders otherwise.

If the deceased has died leaving a valid will, the court may grant probate for the deceased's estate to any executor appointed by a will. The Subordinate Courts have the jurisdiction to grant probate or Letters of Administration where the value of the estate of the deceased is below $\$ 3$ million. If the value of the deceased's assets and effects exceeds $\$ 3$ million, the application is to be filed in the High Court. Figure 1 illustrates the process.

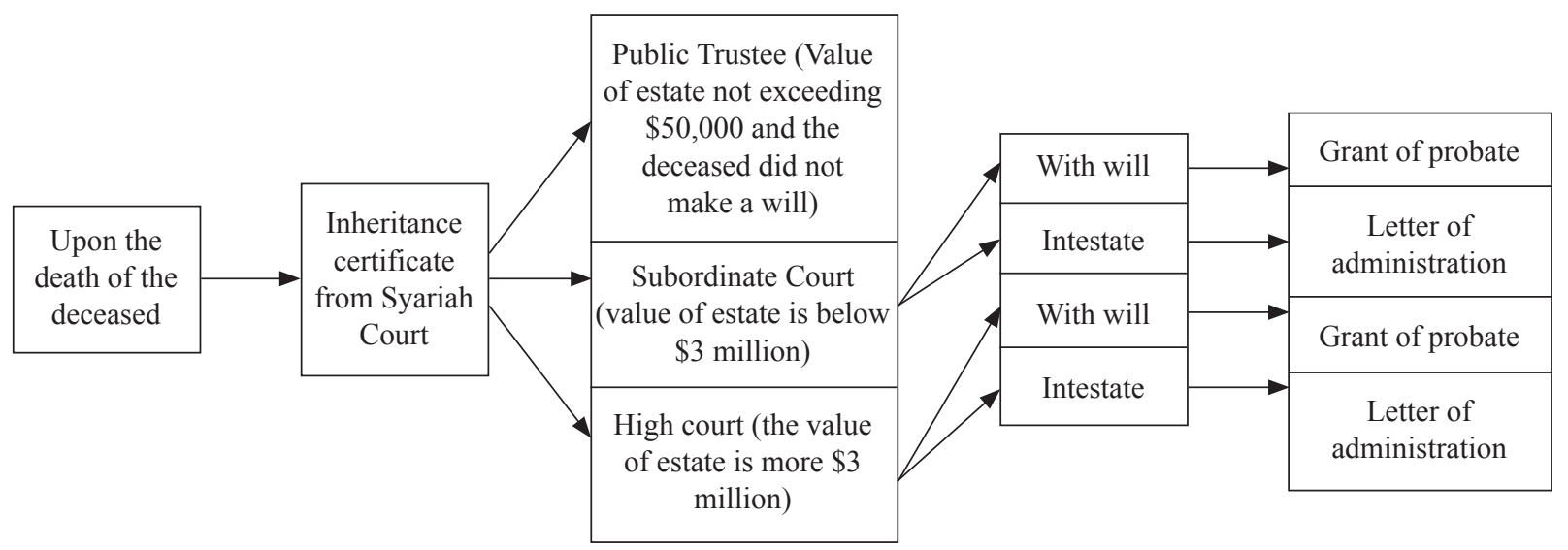

FIGURE 1. Estate administration process for Muslims in Singapore

Sources: Subordinate Courts (2013a); Subordinate Courts (2013b); The Law Society of Singapore (2013) and with some modification by the authors.

The court may request a fatwa ruling from MUIS to determine the validity of the will made by the deceased under Muslim law. It will be recalled that the Syariah Court does not have jurisdiction to determine the validity or disputes pertaining to wills purportedly made under Muslim law, nor does it have any power to enforce them. When the deceased leaves no legal heirs, the estate may go to Baitul Mal (an Islamic charitable trust administered by MUIS). A grant is not a prerequisite for some assets such as CPF monies, flats held under joint tenancy arrangements, and certain types of insurance policies with the nomination to be transferred or distributed. This is due to the fact that $\mathrm{CPF}$ and insurance monies are under purview and subject to the CPF Act and the Insurance Act respectively.

\section{HIBAH FROM THE SHARIAH JURISPRUDENCE POINT OF VIEW}

Hibah is precisely defined as a contract to transfer ownership of existent and deliverable property voluntarily without compensation involved between living individuals whereby the intention and the action of giving the hibah and property transfer must be portrayed clearly in the contract language (Al-Zuhayli 2007; Jantan 2001; Tanzilur-Rahman 1980). Three components comprising of an offer, acceptance and receipt constitute the main features of the hibah contract (Al-Zuhayli 2007; Tanzil-ur-Rahman
1980), for which there is no divergence of views among jurists on the first and second cornerstone, where receipt as a third component is treated differently. Receipt (al$q a b d h)$ as a "binding" condition for the hibah contract is a view shared by the Hanafis and Shafi' is, since for them a new ownership is not established without a receipt. Hence, a hibah becomes binding upon receipt. However, the Hanbalis favour the view that receipt is a validity condition for goods measured by weight and volume. For items not measured by weight or volume, the Hanbalis rule that the hibah becomes binding immediately following the conclusion of the contract. It means that ownership of the hibah is established prior to receipt. Meanwhile, the Malikis view that receipt is neither a validity condition nor a binding condition. In fact, receipt is regarded as a condition for the full effects of the contract to be achieved (Al-Zuhayli 2007).

With regard to recalling the hibah and voiding the contract, the Hanafis is the only school that permits recalling the hibah and voiding the contract on the grounds that the status of the hibah contract is non-binding (Al-Zuhayli 2007; Tanzil-ur-Rahman 1980). On the other hand, other jurists share a view that disallows recalling the hibah and voiding the contract as they consider it is binding except when a father gives a hibah to his child (Al-Zuhayli 2007; Jantan 2001) as long as his child still owns the property (Jantan 2001). The Shafi' is extend this permission from 
the father, grandfathers and great grandfathers who are the child's paternal lineage (Al-Zuhayli 2007). However, they differ on the time that the father is allowed to do so. The Malikis permit rescinding the hibah before receipt only, while the Shafi' is and Hanbalis permit a father to rescind the hibah before or after receipt (Al-Zuhayli 2007). The difference is due to the Malikis' rule that ownership of the hibah object is established with the contract and the contract becomes binding with receipt. As a result it is generally not permissible for the donor to rescind the hibah after receipt (Al-Zuhayli 2007). In addition, the Malikis also add that rescinding is allowed provided that the following five conditions are not violated; the hibah is not given for the purpose of charity and religion, the son must not have married after the hibah was given, the son must not have a deferred debt at that point of time, the object of the hibah must have remained unchanged and neither the donor nor the donee have fallen sick (AlZuhayli 2007). As previously mentioned, since the Malikis allow the donor to stipulate the condition of demanding compensation for the hibah given if he does not receive the appropriate compensation, he may rescind the offer (Al-Zuhayli 2007). According to Tanzil-ur-Rahman (1980), the donor is entitled to revoke his hibah at any time before transferring the possession of the property. The donor is also entitled to revoke his hibah even after taking over possession of the hibah property except for the following circumstances; hibah from husband to wife and vice versa, the donee is the blood relation within a prohibited degree, the donee is dead, the hibah property is no longer in the possession of the donor, the hibah property has physically changed, something is combined with the hibah property and it is impossible to separate the hibah property from its original form or structure and the hibah with anything in exchange.

ISLAMIC ESTATE PLANNING IN SINGAPORE: IMPLICATIONS OF FATWAS ON JOINT-TENANCY AND CPF MONIES

The significant roles of fatwa in clarifying inheritance matters in Singapore can be found in previous studies. These studies reveal the extent to which the conflicts between civil law and Muslim law lead to amendment of the fatwa. According to Abbas (2010), when civil court is faced with a question of Muslim law, it may seek opinion from MUIS about fatwa considered relevant to the dispute. However, it must be noted that the courts are not bound to accept them. This is due to the following possible circumstances; firstly, the court may resist because they find that the ruling contradicts statute or established principle of civil law or secondly, they rule in favour of another interpretation of Muslim law that is applicable to the case. Despite the fact that the fatwa is not binding, its roles remain significant. Based on the feedback received from the community, the Fatwa Committee always reevaluate their existing fatwas. Abbas (2010) calls this process as 'modification of its interpretation of Muslim law.' Most of the time this process is carried out by aligning the law more closely to civil law practice so as to reduce difficulty faced by the Muslims arising from conflict of both context. (Abbas 2010; Mustar \& Nor Muhamad 2013).

The succeeding discussion shows the fact that the Fatwa Committee has been responsible for issuing fatwa legitimising the use of certain instruments that effectively overrides the system of fixed shares prescribed by the Muslim law. The conflict between joint-tenancy contract of Housing Development Board (HDB) property and Shariah law and nomination in CPF and Shariah law are presented in the literature review. Previous studies highlight that fatwas have been issued with the aim to provide the best solution to the Muslims and harmonise the both laws through the mechanism of hibah.

With reference to the joint-tenancy, the contract states that owners have equal rights over the house they co-owned. It does not denote the shares owned by coowners and it should be noted that equal right is not equal share. Shared ownership also does not take into account the payments made by any individual owner. Upon the death of one owner, the surviving one will take over the whole house automatically, without probate proceeding (Rasban 2006).

Mustar and Nor Muhamad (2013) and Rasban (2010a, $2010 \mathrm{~b}$ ) agree that the concept of right of survivorship embedded into the joint-tenancy contract is repugnant to Muslim law. From the Fatwa Committee point of view, their initial fatwa in 1998 decreed that upon the death of one of the joint owner, the surviving joint owner is only entitled to half of the value of the property accrued by virtue of ownership as joint tenant. The remaining half share is for the deceased's legal heirs distributed as per faraid. The conflict between civil law and fatwa begins in an inheritance dispute case, ${ }^{4}$ where finally the general law takes precedence over fatwa. Concerns over the situations that the fatwa has been used by some legal heirs to pressure the surviving joint-tenant to sell the home and distribute the proceeds to other legal heirs and those left behind would not have a roof over their heads have been raised (Abdul Rahman 2012; Rasban 2010b; Rasban 2010a).

The Fatwa Committee reevaluated and reconsidered its fatwa. The challenge facing by the Fatwa Committee was to find the mechanism of estate planning that is consistent with the general law on joint tenancy in Singapore and the effect on the ownership of the property is similar to the right of survivorship. Consequently, as in the most updated fatwa issued in 2008, the fatwa suggests the use of Islamic legal instruments such as hibah ruqba and nuzriah that can harmonise the civil and religious laws on this issue, while at the same time providing an option for Muslims who wish to follow the Islamic laws of inheritance, or faraid. The use of Islamic legal instruments such as hibah ruqba and nuzriah serve as an expression of religious intent by the joint tenant, for jointly held property to vest in the surviving joint tenant, upon death (Abdul Rahman 2012; Mustar \& Nor Muhamad 2013; Rasban 2010b). 
Regarding CPF monies owned by the CPF contributor, fatwa issued in 2010 abrogates the old fatwa issued in 1971. Fatwa Committee had decided in 1971 that it is considered as part of the contributor's estate, to be distributed according to faraid. The nominee(s) of the CPF is only a trustee and is responsible for the distribution of the estate to the heirs according to the faraid rules. The new fatwa recognises the nominee(s) as the rightful owner of the CPF monies upon the death of the $\mathrm{v}$ member. The nomination of CPF is regarded as a contemporary hibah (MUIS 2010; Rasban 2012).

\section{TAKAFUL NOMINATION AND HIBAH OF TAKAFUL BENEFITS IN MALAYSIA}

Problems associated with the lengthy administrative delays of estate administration is mitigated by a nomination in Family Takaful as the process of distributing the takaful benefit to the beneficiaries is not subjected to the Probate and Administration Act 1959 (Act 97) \& Regulations. By practice, prior to the issue of IFSA 2013, a nominee in takaful was regarded as an executor even in the absence of fatwa and an explicit clause in the former Takaful Act 1984. Given the fact that an executor would divide the takaful benefits payable to him according to faraid law, this practice was, as contended by Mohd Noor and Abdullah (2009) and Ismail (2009), perceived to be contrary to the objective of participants' contributions in the takaful account in which it is meant to provide financial help and assistance for the purpose of easing the burden of the participants' dependants Therefore, at present, a mechanism known as 'hibah of takaful benefits' has been introduced for the purpose of distribution of takaful benefits to a particular or sole beneficiary. The engagement of hibah of takaful benefits is a manifestation of the Bank Negara Malaysia's (BNM) resolution in 2003 which allows the hibah of takaful benefits by means of conditional hibah to a particular beneficiary and it has been in operation ever since. Provision of law in relation to this matter only materialised in 2013 when the Islamic Financial Services Act (IFSA) was issued.

This type of hibah of takaful benefits is a conditional hibah, in which the hibah is an offer to the recipient of hibah for only a specified period. In the context of takaful, the takaful benefit is both associated with the death of the participant as well as maturity of the certificate. If the participant remains alive upon maturity, the takaful benefit is owned by the participant but if he dies within such a period, then hibah shall be executed. A participant has the right to revoke the hibah before the maturity date because conditional hibah is only deemed to be completed after delivery is made (qabadh). Participants have the right to revoke the hibah to one party and transfer it to other parties or terminate the takaful participation if the recipient of hibah dies before maturity (BNM n.d.; IFSA 2013).

\section{RESEARCH METHODOLOGY}

This study is qualitative research in nature. The primary data is obtained through semi-structured interviews and secondary data is derived from the references to statutes and fatwas. Semi-structured interviews were conducted in September 2012. In relation to the sampling of the semi-structured interviews, the study decided to use purposive sampling. The Islamic estate planners selected for the interview were Barakah Capital Planners Pte. Ltd. and HTHT Advisory Services Pte. Ltd. who are wellknown professionals that have needed facts and relevant information sought for via in-depth investigation. These two companies were extensively involved in disseminating information and conveying knowledge of Islamic estate planning by writing actively on Islamic estate planning in magazines, books and conference papers. Respondent from the Barakah Capital Planners Pte. Ltd was the Islamic estate planning consultant of the company and respondent from the HTHT Advisory Service Pte. Ltd was the founder of the company itself. These two respondents represented the supply-side of the industry.

In addition to the service providing companies, one interviewee was the Head, Office of the Mufti, MUIS and an officer of Asset Department of MUIS. Respondent from Mufti Department of MUIS is important to elaborate the fatwa issued in validating the revocable nomination of insurance for Muslims in Singapore. The other respondent from Asset Department of MUIS was responsible in handling the inheritance matter of Muslims in Singapore. The questions designed for them were meant to get information on the application of the insurance nomination, and their views on the analogy approach used by the Fatwa Committee.

Data from the semi-structured interviews were analysed using the narrative approach with a thematic analysis. This analysis method was chosen because it mainly placed emphasis on the content of the response by maintaining the language of the response as far as possible. Main themes were constructed from the answers provided and then they were segregated into several subthemes. Such technique helped to analyse these responses in detail by placing responses which were similar under the same theme. Data from the semi-structured interviews were cross-checked with the secondary data which were analysed using content analysis.

\section{FINDINGS AND DISCUSSION}

NOMINATION OF INSURANCE POLICY IN SINGAPORE: STAGES OF FATWA AMENDMENTS AND PRESENT STATE OF AFFAIRS

Nomination of insurance policy in Singapore is under the provision of Insurance Act and it applies to Muslims as well. Insurance companies in Singapore provide both options, namely a revocable or irrevocable nomination for 
the policyholders to choose from. Fatwas with regards to the nomination of insurance policy have been amended and issued with the purpose of harmonising the Syariah law with Insurance Act S49L (Rasban 2012).

Information from secondary sources and interview are similar in terms of the application of the revocable nomination and the chronology of the fatwa amendments which are summarised as follows. The stages of amendment of the fatwas are explicitly elaborated in Administration of Muslim Law Act (AMLA). ${ }^{5}$ To begin with, as stated in MUIS (2012) it must be noted that the Fatwa Committee of MUIS allows the purchasing of insurance by virtue of socio-economic factors. The Fatwa Committee acknowledges that Muslim scholars ${ }^{6}$ differ in their opinions on purchasing of insurance. While some view it as permissible in Islam on the basis of protecting the welfare of Muslims, others view it as prohibited due to the aspects of syubhah and gharar, whether in the process of how the fund is accumulated, or how it is invested. In its discussion, the Fatwa Committee takes into consideration the changes to the economic and demographic aspects that lead someone to plan for his/her finances whether in preparation for old age or for his/her family's future needs. Due to the limited investment options for low and middle income members of the community, some of them may choose to undertake financial planning in the form of insurance. The Fatwa Committee is of the opinion that a nomination for insurance is an instrument which can fulfil the needs of those who plan for their insurance monies to benefit those in need. On this basis, a fatwa was issued in 2007 which allows insurance nomination for Muslims. However, only the irrevocable nomination was allowed as this form of nomination. Irrevocable nomination is a form of nomination where the policy holder loses all rights over the payouts of the policy, because all benefits are payable to the nominee(s). If a policy holder wishes to revoke or amend the nomination, he/she requires consent from each nominee or a trustee (MUIS 2012). To the Fatwa Committee of MUIS, irrevocable nomination was seen as fulfilling the description and requirement of hibah. A nominee in an irrevocable nomination is a valid hibah recipient and the nominee is allowed to own proceeds and is not required to return it to the estate (Mohd. Shuhaimy 2012; MUIS 2012)
However, in 2011, the Fatwa Committee of MUIS observed a number of limitations with irrevocable nomination which could pose difficulties to the insurance policyholder. The limitations are as follows: The requirement that only a spouse or children can be made nominees (beneficiaries); an irrevocable nomination cannot be revoked or amended even after a divorce has taken place (except with the consent of the nominee(s); any payout from the life benefits of the insurance policy (if any) is payable only to the nominee(s). This means that if the policy holder is involved in an accident, he/she will not benefit from the insurance payout; if the nominee predeceased the insurance policy holder, the nominee's portion from the nomination is considered as part of his/her estate, and does not return to the insurance policy holder. Consequently, the Fatwa Committee began to allow the revocable nomination in $2012 .{ }^{7}$ Revocable nomination is a form of nomination where the policy holder still retains full right to amend or revoke the nomination. All life benefits will be payable to the policy holder and only death benefits are payable to the nominee(s) (MUIS 2012). The fatwa was made by means of drawing an analogy between hibah and revocable nomination. MUIS (2012) states that the Fatwa Committee finds similarities between hibah and revocable nomination on the ground that firstly, hibah is revocable provided that al-qabdh has not taken place. In insurance nomination, al-qabdh does not take place before the death of the policy holder. Secondly, it is made while the insurance policy holder is still alive. Thirdly, by making an official nomination, it shows that there is a clear testimony of the policy holder commitment to give away his/her monies to the nominee(s). However, Mohd. Shuhaimy (2012), provides another two similarities between hibah and revocable nomination (see Table 1). He justifies that both are similar because firstly, the recipient of hibah as well as monies payable by the insurance company are not confined to any specific person and secondly, revocable insurance nomination belongs to the policy holders which fulfils one of the ruling of hibah. The Fatwa Committee, however further advises the Muslim community against making a nomination with the intention of causing injustice towards beneficiaries.

TABLE 1. Similarity between revocable insurance nomination and concept of Hibah in Islamic Law

\begin{tabular}{ll}
\multicolumn{1}{c}{ Hibah } & \multicolumn{1}{c}{ Revocable insurance nomination } \\
\hline $\begin{array}{l}\text { The Wahib or giver has the right to revoke or change his/her } \\
\text { hibah provided no al-qabdh (physical acceptance of a gift) has } \\
\text { taken place. }\end{array}$ & $\begin{array}{l}\text { A policyholder also has the right to revoke his/her nomination } \\
\text { prior to death. } \\
\text { Can be given to both faraid and non-faraid beneficiaries. }\end{array}$ \\
$\begin{array}{l}\text { The gift must be owned by the gifter. } \\
\text { Can be made for any legal entity. }\end{array}$ & Policy is owned by policy holder. \\
\hline
\end{tabular}

Source: Mohd. Shuhaimy (2012) 
A study by Rasban (2012) provides constructive feedback on the nomination of insurance policy among Singaporean Muslims. Rasban (2012) disagrees with the latest fatwa on this matter. He views this fatwa, which is meant to harmonise the Syariah law with Insurance Act S49L, as a proactive solution from the Fatwa Committee in order to solve the estate planning issue among Singaporean Muslims. However, Rasban (2012) argues that the current fatwa that allows the revocable nomination is not in harmony with the Administration of Muslim Law Act (AMLA) S111 since AMLA S111 regards the nominee as a trustee who is responsible of disposing the benefit based on faraid if there is no other wealth transfer document. For instance if a hibah contract is signed by the insured during his/her lifetime on that policy. To conclude, we believe that the main purpose of the amendment of the fatwa in Singapore is to reinforce the mechanism used for estate planning purposes.

\section{FATWA IS RELATIVELY MORE IMPORTANT IN SINGAPORE}

MUIS has issued a fatwa with regard to revocable nomination that clarifies the validity of the product at the national level. The need for such a fatwa in Singapore is deemed to be more important in comparison to Malaysia, taking into account that Muslims in Singapore are bound to the jurisdiction under Insurance Act S49L. In Malaysia, the Islamic Financial Services Act 2013 has just been issued and clearly outlined the roles of nominees in takaful in which the nominee could be appointed as an executor or sole beneficiary. Thus in Malaysia, a nomination cannot simply be recognised as an analogy to hibah unless it is stated clearly by the takaful participants that the nominee is the beneficiary under conditional hibah.${ }^{8}$ However, there is no hibah for a nominee in insurance in Malaysia since conventional life insurance is illegitimate for Muslims according to the fatwa issued on 15 June 1972. Mohd. Noor and Abdullah (2009) review that the fatwa issued by the Malaysian National Fatwa Council on illegitimacy of conventional life insurance appears to be inconsistent. Despite the prohibition of conventional life insurance, there is a fatwa stating that money paid by conventional insurance must be distributed among the insured's legal heirs by the nominee appointed according to the faraid law on 20 September 1973.

Other information obtained from a respondent indicates that estate planning in Singaporewith regard to insurance is more nomination-based rather than willbased. He said,

"In Singapore, it can be challenged if there is no nomination."

Hence, we believe this is another factor that has been taken into account by the Fatwa Committee of MUIS. The 'superiority of nomination' is compromised with the mandatory rules of Islamic inheritance law through validation of revocable nomination of insurance policies.
Despite the presence of fatwa in Singapore, it cannot bind the decisions that will be made by the court in resolving a dispute. The court may reach a different verdict which is not in line with the fatwa issued by the Fatwa Committee of MUIS. However, the purpose of amending the fatwa should be given some credit. In Singapore, where options are limited and civil law supersedes the Islamic law, fatwa that allows them to make a revocable nomination of insurance policies assists them in developing an action plan for their estate planning based on their circumstances that vary across different groups of people.

\section{FATWA APPLIES TO THE TAKAFUL FUND}

Fatwa in regards to nomination of insurance policies in Singapore also applies to the takaful fund. This is observed from the following respondent's statement:

"In Singapore, when we say insurance, it covers takaful as well."

However, the fatwa itself treats both accounts in the takaful fund in the same manner. Scholars in Malaysia have argued the inheritability of the Participant Risk Fund (PRF) (previously known as the Participant Special Account or PSA). Under the takaful plan, the contributions paid by the participants in Family Takaful are channelled to the Family Takaful Fund, which goes into different accounts, mainly known as the Participant Investment Fund (PIF) (previously known as the Participant Account or PA) and PRF. PIF is an individual investment account used to generate profit. PRF is a pooled risk fund where the participants contribute on a tabarru'(donation) basis. The takaful benefit which is to be paid by the takaful operator to the nominee of the participant consists of the balance from the PIF prior to the death of the participant and the unpaid amount of the takaful contribution from the date of the participant's death until the date of maturity of the takaful certificate from the PRF (Abdullah \& Abdul Aziz 2010). The inheritability of PRF account (tabarru' portion) is debatable.

There is no question regarding the inheritability of the money in the PIF as it is part of the deceased's estate. Scholars and takaful practitioners are of the opinion that money from the PIF is considered as inheritance since this money is the right of the participant during his life (Mohd Noor \& Abdullah 2009; Ismail 2009). On the other hand, there are different opinions on the status of the tabarru' portion. Money from the PRF (tabarru'account) which is considered a takaful benefit, is not part of the inheritance since it is not the right of the participant during his life. Unfortunately, with regard to this disagreement, IFSA is largely silent. ${ }^{9}$

\section{AN ADDITIONAL HIBAH DOCUMENT IS RECOMMENDED}

Even though a revocable nomination is recognised by the Fatwa Committee of MUIS as a 'contemporary hibah', an additional hibah document is recommended on top of the revocable nomination of insurance policies with the 
purpose to avoid legal issues. One of interviewees however stressed that regardless of the existence of the hibah document made for this purpose, it can be challenged if there is no nomination. This implies that he believes that the jurisdiction provided by Insurance Act S49L and fatwa validation on a revocable nomination are sufficient to convince Muslims that they can dispose the insurance monies as hibah

This necessity of having another additional agreement is highlighted in the latest fatwa issued in 2008 by MUIS on joint tenancy in Singapore due to the feedback received on problems faced by Muslims on the joint tenancy agreement. The law gives the right to the survivor to automatically inherit the deceased's share of the property. Muslims, on the other hand, as stated by the previous fatwa, must dispose the shares of the deceased in accordance with faraid. The latest fatwa implies that if there is an arrangement or agreement that has been made between the joint tenants either through a hibah ruqba or a nuzriah vow, which expressly states that the property is to be given wholly to the surviving joint tenant, in the event of the death of one of the joint tenants, then the entire property shall vest in the surviving joint tenant. ${ }^{10}$ This leads to the finding that the same factor triggers both amendments on joint tenancy and insurance nomination. However, it is somewhat questionable that the current fatwa on the validity of the irrevocable nomination does not include 'the other arrangement or agreement' made between the policyholder of the insurance and the nominee which acknowledges the additional legal document to validate the hibah contract as we can observe in the fatwa on joint tenancy.

Rasban (2010b) views that the latest fatwa on the joint tenacy is consistent with the present law on joint tenancy in Singapore. 'The arrangement or agreement' which has been made could be additional legal document such as a hibah deed on their joint tenancy property ${ }^{11}$ that can validate the conditional hibah or nuzriah ${ }^{12}$ vow. However, Rasban (2010b) raises his concern that this is not an easy task due to the misunderstanding among Muslims in Singapore. People believe that making another legal document is unnecessary since the intention to give away the property to their spouse upon the death is very clear when they sign the joint tenancy contract.

The same thought is shared in Malaysia. One may view that he/she can make hibah of takaful benefits by filling out the nomination form provided by the takaful operator at no cost. Therefore, he/she might think that there is no need to make a hibah contract and pay an additional cost to another estate planning company. Another possible situation that might occur is that a client who has made hibah by filling out the nomination form, at the same time, gets another hibah service from an Islamic estate planner. According to Nor Muhamad (2011), the hibah documentation that is made by the law firms or other companies is to verify the hibah in terms of Shariah legislation. It may become an evidence that the participant has given the property to the hibah recipients. In Malaysia, the only Islamic estate planning company which provides such service of making a hibah document of Takaful benefits is Wasiyyah Shoppe Sdn. Bhd. (WSSB) (Kamarudin \& Alma'amun 2012). However, the significance of having an additional legal document must be reconsidered since IFSA provides a clause that indicates a nomination made on a nomination form of the takaful provider could not be challenged by any other means ${ }^{13}$ and it shall not form part of the estate of the deceased takaful participants. ${ }^{14}$

\section{THE CONFLICT OF LAWS AND FATWA}

AMLA clearly spells out that Muslims estates must be distributed according to Islamic law of inheritance. In light of this, the previous fatwa which stated that insurance monies received by nominees are merely held on trust for the beneficiaries under the faraid, this was in sync with the legal position in the civil law. When the fatwa changes to the most recent one, the position of the fatwa as it now stands is that insurance monies go to the nominee and apparently, in this case, it is not in line with provisions made in AMLA. This is deliberated by the interviewee in which he mentioned:

"The new fatwa says that an revocable nomination can be made in insurance. They (the fatwa committee) say it is hibah. State law under AMLA says, any nomination must refer to Muslim Law. Fatwa is not a Muslim law."

"State law says that we must dispose according to Muslim law. State law does not refer to fatwa. Muslim law means there is hibah, faraid, all of that. For example, if I made a nomination for my younger sister, which is actually a revocable nomination in insurance, according to insurance legislation, I can give it to my younger sister. But, going back to the State law, a trustee must go back to faraid.'

We believe that from his perspective, he still upholds the previous fatwa and views a nomination and hibah as two different forms. He stresses that a nomination is subject to State law. State law has outlined that insurance policies with a nomination must be distributed according to faraid. In addition, the interviewee insists that nothing can override the legislations. These important findings are contained in his further comments:

"State law is Shariah compliant. Fatwa cannot be followed since it always changes. How are we supposed to follow the fatwa? The priority is wrong. How could we change Quran and Hadith with the fatwa?"

"How could we say that a nomination (revocable nomination) is hibah? ..... In Singapore, State law must be followed."

Undoubtedly, MUIS has the power to issue fatwas on questions of Islamic law that arise in cases under the jurisdiction of the civil court is, but the treatment of MUIS fatwas by the civil courts is uncertain. Civil courts, when faced with a question of Muslim law, are not obliged to seek an opinion from MUIS. They may be informed about fatwas considered relevant to the dispute but they are not bound to accept them. However, civil courts generally abide by MUIS' fatwas unless firstly, the fatwas contradict 
the statute or established principle of civil law or and secondly, they rule in favor of another interpretation of Muslim law that is applicable to the case. The current scenario with regard to the new fatwa on revocable nomination, can be perceived as an effort made by MUIS to modify its interpretation of Muslim law. By aligning it more closely to civil law practice, the difficulty faced by the Muslim public arising from conflict of law issues (Abbas 2012) can be reduced.

\section{IMPLICATIONS AND RECOMMENDATIONS}

Malaysia and Singapore were British colonies and therefore the legacy of British jurisdiction still remains which is manifested by the way civil law regulates the procedures of estate administration and settlement (Muhammad 2007). The jurisdiction power of the Syariah Court is limited only to the issuance of certificate of inheritance. Dying intestate and testate are dealt with differently, and under such circumstances, Muslims in both countries should anticipate the consequences and the authorised bodies that they need to deal with. The process could be difficult, costly and time-consuming. Notwithstanding the existence of civil law as the legacy of the British administration, the Islamic inheritance system must be taken into consideration in the implementation of estate planning for Muslims in both countries. The mechanism of estate planning either as a revocable nomination of the insurance policy or hibah of takaful benefits is meant firstly, to harmonise the need of the Muslim community and the existing legislations, and secondly to avoid the hassle of the estate administration and distribution process.

A straightforward comparison between what has been practiced in Singapore and Malaysia cannot be made since the foundation and operational structure in both countries are different. Nevertheless, experiences from both countries are beneficial for the development of insurance, takaful and estate planning industries. Furthemore, in Malaysia, the structure and operational framework have been in operation for quite sometime. The loopholes in the system has been corrected especially with the issue of IFSA (2013) which states the provision of law for both nomination and hibah. On the other hand, in Singapore, the fatwa has been put in place but the development of the operational structure of this estate planning mechanism is yet to grow. Therefore, the crucial step to be taken to support this mechanism of the estate disposal in Singapore is to enhance the related jurisdiction, namely the AMLA. The AMLA must be amended and should embraced the revocable nomination as part of the way for Muslims to dispose their insurance monies.

The innovation of hibah in the takaful industry is quite aggressive in Malaysia. With regard to Singapore, we suggest that firstly, takaful operators in Singapore should engage with experts from Malaysia to come up with similar features of hibah of takaful benefits that suit the Singaporean Muslims' needs and is able to mitigate the existing jurisdiction. Secondly, should the fatwa be reviewed in the future, the Fatwa Committee of MUIS is advised to take into account the problems in distinguishing inheritability of money from PIF and PRF accounts of takaful funds. In order to solve this problem, the approach taken by Takaful Ikhlas Sdn. Bhd. could be a good example in which hibah of PIF is not allowed. Nominees should distribute takaful benefits from PIF according to faraid. Money from PRF, however, is valid to be given to the close heirs through 'a proposed hibah.' MUIS efforts to this extent must be appreciated. Eventhough these fatwas have been criticised such as in Rasban (2012), ${ }^{15}$ the fatwas at some point of time are useful and effective in harmonising between Islamic law and civil litigation as argued in Abbas (2010) and Mustar and Nor Muhamad (2013).

Another crucial finding indicates that additional documents to validate hibah transfer in the form of money paid either by the insurance company or takaful providers should be prepared to ensure that it does not violate Shariah law. However, the significance of having an additional legal document in the case of Singapore must be explored at greater length. People must be informed whether the additional legal document can be challenged in court by referring to precedent cases.

This study provides useful insights for extensive research in the future. The distribution of insurance monies and takaful benefits are part of the intergenerational transfer from the economic point of view which is related to inheritance. There is also a potential for the empirical studies on bequest or inter vivos motives among insurance policy holders and takaful participants. In addition, the scope of the study can be extended to various disciplines, for example the validity of revocable nomination in the contextual form of Islamic jurisdiction and the perception of the public on the fatwa on nomination.

To conclude, the difference between Malaysia and Singapore lies in the fact that Malaysia had never recognised the nomination as an analogy to hibah. Where revocability and the interest of the takaful participant are highly concerned, conditional hibah is the solution to this problem. Conditional hibah has been used widely in estate planning and it is not limited to takaful benefits.

\section{CONCLUSION}

The latest innovation in Malaysian Islamic estate planning is engaging hibah in takaful products. However, in Singapore, revocable nomination is perceived to be similar to hibah and therefore the Fatwa Committee of MUIS has come up with the permissibility of a revocable nomination of insurance policies. This study provides the recommendations which could benefit the stakeholders. This paper is the first attempt to delve into the issue of hibah, nomination and takaful beyond the Malaysian contextual form. We hope that further research will be carried out to enrich the literature. 


\section{ENDNOTES}

1 It is beyond the scope of this study to provide details on these aspects of the hibah of takaful benefits derived from the previous research.

2 A vow which expressly states that the property is to be given wholly to the surviving joint tenant, in the event of death of one of the joint tenants, then the entire property shall vest in the surviving joint tenant (MUIS 2008).

3 Section 111(1) of AMLA is as follows: Notwithstanding anything in the provisions of the English law or in any other written law, no Muslim domiciled in Singapore shall, after 1st July 1968, dispose of his property by will, or by any nomination under section $49 \mathrm{M}(2)$ of the Insurance Act (Cap. 142), except in accordance with the provisions of and subject to the restrictions imposed by the school of Muslim law professed by him (AMLA 2009).

4 In the case of Shafeeq bin SalimTalib vs Fatimah bte Abud bin Talib.

$5 \quad$ See Chapter 3, Section 32 AMLA 2009.

6 AMLA quotes the following scholars namely Dr. Mustaa Zarqa', Dr. Ali Jumaah, the Mufti or Egypt and House of Fatwa of Egypt (Dar A1-Ifta' Al-Misriyah).

7 The original fatwa says as follows - This issue rose following the amendments to the Insurance Act in September 2009. This amendment allows insurance policy holders in general to make a revocable nomination. A consequential amendment was subsequently made to section 111(1) of the Administration of Muslim Law Act (AMLA). The consequential amendment disallows Muslims from making a revocable nomination except when it is in accordance to Islamic law.

$8 \quad$ IFSA (2013) states that, "A takaful participant who has attained the age of sixteen years may nominate an individual to receive takaful benefits payable upon his death under the takaful certificate, either as an executor, or as a beneficiary under a conditional hibah by notifying the licensed takaful operator in writing the name, date of birth, national registration identity card number or birth certificate number and address of the nominee."

9 With regard to the effect of nomination in takaful, IFSA (2013) only rules that 'a nominee under subparagraph 2(1) shall receive the takaful benefits payable under a takaful certificate either as an executor or as a beneficiary under a conditional hibah, as the case may be, as stated in the nomination form by the takaful participant.'

10 The Fatwa Committee decrees that: (i) If no other arrangement or agreement has been made between the joint owners of a property, upon the death of one of the joint owners, the surviving joint owner will not have full ownership of the property. The surviving joint owner shall only be entitled to half $(50 \%)$ of the value of the property. This $(50 \%)$ entitlement arises from his/her position as a joint tenant; (ii) If, however, other arrangements or agreements have been made between the joint tenants, either through a "hibah ruqba" (ruqbagift) or a "nuzriah" (vow) which expressly states that the property is to be given wholly to the surviving joint tenant, in the event of the death of one of the joint tenants, then the entire property shall vest in the surviving joint tenant. This is consistent with the present laws on joint-tenancy in Singapore.

11 Both spouses pledge their intention in the hibah ruqba of giving the property to the other spouse (Rasban 2010).
12 Nuzriah comes from the word 'nazar' - a vow to God. Nuzriah is a vow which is not associated with either conditions or time and it can be executed later. In Singapore, it is used as a mean of wealth transfer. A vow is revocable without the need for consent from anyone. It can take effect before or after death and be for the benefit of legal or non-legal heirs with no constraint on the quantum. For example, for a man intending to give all of his estate to his daughters, MUIS would recommend to him to use nuzriah (Rasban 2010)

13 IFSA (2013) decrees that 'a nomination shall not be revoked by a will or by any other act, event or means.'

14 IFSA (2013) rules that 'a nomination by a takaful participant pursuant to subparagraph 2(1) for a nominee to be a beneficiary under a conditional hibah, shall, notwithstanding any written law, have the effect of transferring ownership, and shall transfer ownership, of the takaful benefits payable to the nominee upon the death of the takaful participant and such takaful benefits so transferred shall not form part of the estate of the deceased takaful participant or be subject to his debts.'

15 See another example of controversial fatwa in relation to nuzriah in Abdul Rahman (2012).

\section{ACKNOWLEDGEMENT}

Funding for this project was provided by the Universiti Kebangsaan Malaysia (GGPM-2011-045). The authors would like to thank the Islamic Religious Council of Singapore (MUIS), Barakah Capital Planners Pte. Ltd. and HTHT Advisory Services Pte. Ltd. for their insights and assistance.

\section{REFERENCES}

Ab Ghani, A.M. 1999. Sistem Kewangan Islam dan Perlaksanaan di Malaysia. Kuala Lumpur: Jabatan Kemajuan Islam Malaysia.

Abbas, A.N. 2010. The Islamic legal system in Singapore. Pacific Rim Law \& Policy Journal 21(1): 164-187.

Abdul Rahman, N.A. 2012. Muslim personal law and citizens' rights: The case of Singapore. Asian Journal of Comparative Law 7(1): 1-29.

Abdullah, N.I. \& Abdul Aziz, N.A. 2010. Case studies of the practice of nomination and hibah by Malaysian Takaful operators. ISRA International Journal of Islamic Finance 2(2): 67-100.

Administration of Muslim Law Act (AMLA). 2009. Available at http://statutes.agc. gov.sg/aol/search/display/view. w 3 p; page $=0$; query $=$ DocId $\% 3$ A 3 e 90 fc 65 -b 364 434bb2d-ced1d9608640\%20\%20Status\%3Ainforce $\% 20$ Depth\%3A0;rec=0\#legis

Al-Zuhayli, W. 2007. Financial Transactions in Islamic Jurisprudence, translated by M.A. El-Gamal, Vol. 1, 2nd edition. Damascus: Dar al-Fikr.

Baharin, M.I. 2011. RM42 bilion harta beku. Available at http:// www.hmetro.com.my/articles/RM42bilionhartabeku/ Article

Bank Negara Malaysia. 2012. Takaful operator: List of licensed insurance companies \& takaful operators in Malaysia. Available at http://www.bnm.gov.my/index.php?ch=13\& cat $=$ insurance $\&$ type $=T K F \&$ fund $=0 \& c u=0$. 
Bank Negara Malaysia. n.d. Resolution of shariah advisory council of Bank Negara Malaysia. Available at http:// www.bnm.gov.my/guidelines/01_banking/04_prudential_ stds/07_sha riah_resolution.pdf.

Islamic Financial Services Act (IFSA). 2013. Available at http:// www.bnm.gov.my/index. php?ch=en_legislation\&pg=en legislation_act\&ac $=1080$

Islamic Religious Council of Singapore (MUIS). 2010. Fatwa on CPF nomination (2010) Available at http://www.muis. gov.sg/cms/oomweb/fatwa.aspx?id=15666.

Islamic Religious Council of Singapore (MUIS). 2012. Fatwa on revocable insurance nomination. Available at http:// www.muis.gov.sg/cms/oomweb/fatwa.aspx?id=16900

Islamic Religious Council of Singapore (MUIS). 2008. Fatwa on joint tenancy. Available at http://www.muis.gov.sg/cms/ oomweb/fatwa.aspx?id=14386 .

Ismail, A. 2009. Nomination and hibah issues in the takaful industry. Paper presented at the ISRA Shariah Conference on Takaful, 7 May 2009, International Shari'ah Research Academy for Islamic Finance (ISRA), Kuala Lumpur.

Jantan, O. 2001. Pedoman Mu'amalat dan Munakahat (Civil Transaction) (Guidelines of Muamalat and Munakahat (Civil Transaction). Singapore: Pustaka Nasional Pte Ltd.

Kamarudin, M.K. \& Alma'amun, S. 2012. Hibah of takaful benefits in Islamic estate planning: A case study at the Wasiyyah Shoppe Sdn. Bhd (WSSB). Proceeding 3rd International Workshop in Islamic Economic Theory, edited by A. Tohirin, Jogjakarta, 164-179.

Mohd Noor, A. \& Abdullah, A. 2009. Ownership and hibah issues of the takaful benefit. Journal of Islamic Economics, Banking and Finance 5(3): 35-48.

Mohd. Shuhaimy, I.H. 2012. Fatwa on revocable insurance nomination: Context and ruling. Paper presented at the Conference Financial Planning For Muslims: Current Issues in Insurance and Trusts, 30 August, M. Hotel, Singapore.

Muhammad, A. 2007. Ke arah penyelesaian harta pusaka kecil yang lebih bersepadu, cekap dan cemerlang. In Konvensyen Perwarisan Harta Islam. Kuala Lumpur: Amanah Raya Berhad.

Mustar, S. \& Nor Muhamad, N.H. 2013. Kedudukan jointtenancy dan kepentingannya dalam pemilikan rumah menurut perspek tif undang-undang Islam dan Sivil di Singapura. Jurnal Teknologi 65(1): 29-37.
Nor Muhamad, N.H. 2010. Pemakaian prinsip hibah dalam sistem kewangan Islam di Malaysia: Tumpuan kepada industri perbankan Islam dan Takaful. Jurnal Teknologi 52: 69-81.

Nor Muhamad, N.H. 2011. Hibah dalam Undang-Undang Malaysia. Johor Bahru: Penerbit UTM Press.

Rasban, S. 2006. Joint Tenancy in Muslim La., Singapore: HTHT Advisory Services Pte Ltd.

Rasban, S. 2010a. Critical Analysis of AMLA in Estate Matters. Singapore: HTHT Advisory Services Pte Ltd.

Rasban, S. 2010b. Hibah Al Ruqba and Joint Tenancy in Shari'ah Law. Singapore: HTHT Advisory Services Pte Ltd.

Rasban, S. 2012. Contemporary Studies on Estate Matters: Dying Intestate. Singapore: HTHT Advisory Services Pte Ltd.

Subordinate Courts. 2013a. Some matter to consider before deciding to file an application for a grant. Available at http://app.subcourts.gov.sg/Data/Files/File/ InforBooklet_Brochures/InforProbate_StepByStep_ ConsiderBeforeFiling.pdf

Subordinate Courts. 2013b. Introduction to probate and administration. Available at http://app.subcourts.gov.sg/ civil/page.aspx?pageid $=10967$

Tanzil-ur-Rahman. 1980. A Code of Muslim Personal Law. Pakistan: Islamic Publishers.

The Law Society of Singapore. 2013. Faraid or Muslim inheritance law. Available at http://www.lawsociety.org. sg/forPublic/YoutheLaw/FaraidorMuslimInheritanceLaw. aspx

Suhaili Alma'amun (corresponding author)

Faculty of Economics and Management

Universiti Kebangsaan Malaysia

43600 UKM Bangi, Selangor, MALAYSIA.

E-Mail: sba7611@gmail.com; suhaili@ukm.edu.my

Mohd Khairy Kamarudin

Faculty of Entrepreneurship and Business

Universiti Malaysia Kelantan

16100 Pengkalan Chepa, Kelantan, MALAYSIA.

E-Mail: khairyaljoni@gmail.com; khairy.k@umk.edu.my 
